\title{
Inconsistent reporting, regulations and market demand affect abundance indices of sharks caught by pelagic longliners off southern Africa
}

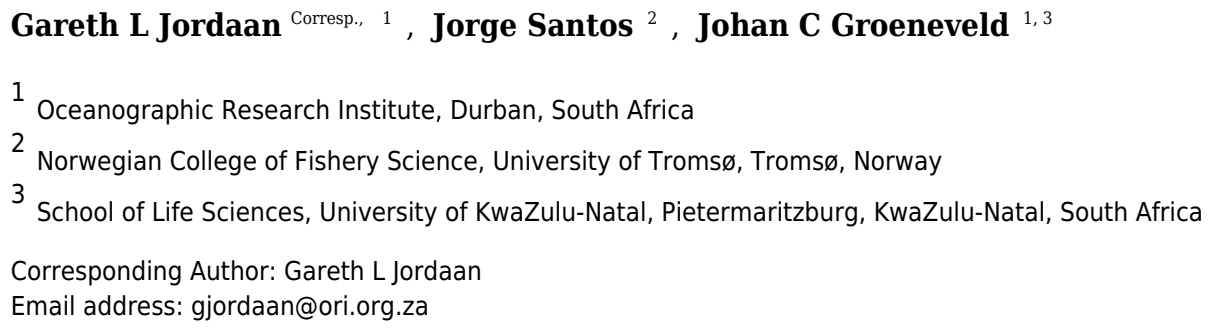

The assumption of a proportional relationship between catch-per-unit-effort (CPUE) and the abundance of sharks caught by pelagic longliners is tenuous when based on fisher logbooks that report only retained specimens. Nevertheless, commercial logbooks and landings statistics are often the only data available for stock status assessments. Logbook data collected from local- and foreign pelagic longline vessels operating in four areas off southern Africa between 2000 and 2015 were used to construct standardized CPUE indices for blue sharks Prionace glauca and shortfin makos Isurus oxyrinchus. Generalized linear mixed models were used to explore the effects of year, month, vessel, fleet and presence of an observer on blue shark and shortfin mako variability. Landing statistics and auxiliary information on the history of the fishery, regulation changes, and market factors were superimposed on the CPUE indices, to test hypotheses that they would influence CPUE trends. Indices in the West and Southwest (Atlantic) areas were elevated for both species, compared to the South and East (Indian Ocean). The scale of year-on-year CPUE increments, up to an order of magnitude for blue sharks, reflected occasional targeting and retention, interspersed with periods where blue sharks were not caught, or discarded and not reported. Increments were smaller for higher value shortfin makos, suggesting that indices were less affected by unreported discarding. CPUE indices and landings of both shark species have increased in recent years, suggesting increased importance as target species. Analysis of logbook data resulted in unreliable indicators of shark abundance, but when trends were interpreted in conjunction with landings data, disaggregated by area and month, and with foreknowledge of market demand and regulation changes, anomalies could be explained. 
1 Inconsistent reporting, regulations and market demand affect

2 abundance indices of sharks caught by pelagic longliners off

3 southern Africa

4

5 Gareth L. Jordaan ${ }^{a}$, Jorge Santos ${ }^{b}$ and Johan C. Groeneveld ${ }^{a, c}$

6 aceanographic Research Institute, 1 King Shaka Avenue, Durban, South Africa

7 bNorwegian College of Fishery Science, University of Tromsø, NO-9037, Tromsø, Norway

8 'School of Life Sciences, University of KwaZulu-Natal, Pietermaritzburg, KwaZulu-Natal, South

9 Africa

10

11 Corresponding author:

12 Gareth L. Jordaan

13 Email address: jordaan.gareth@gmail.com 


\section{Abstract}

23 The assumption of a proportional relationship between catch-per-unit-effort (CPUE) and the

24 abundance of sharks caught by pelagic longliners is tenuous when based on fisher logbooks that

25 report only retained specimens. Nevertheless, commercial logbooks and landings statistics are

26 often the only data available for stock status assessments. Logbook data collected from local-

27 and foreign pelagic longline vessels operating in four areas off southern Africa between 2000

28 and 2015 were used to construct standardized CPUE indices for blue sharks Prionace glauca and

29 shortfin makos Isurus oxyrinchus. Generalized linear mixed models were used to explore the

30 effects of year, month, vessel, fleet and presence of an observer on blue shark and shortfin mako

31 variability. Landing statistics and auxiliary information on the history of the fishery, regulation

32 changes, and market factors were superimposed on the CPUE indices, to test hypotheses that

33 they would influence CPUE trends. Indices in the West and Southwest (Atlantic) areas were

34 elevated for both species, compared to the South and East (Indian Ocean). The scale of year-on-

35 year CPUE increments, up to an order of magnitude for blue sharks, reflected occasional

36 targeting and retention, interspersed with periods where blue sharks were not caught, or

37 discarded and not reported. Increments were smaller for higher value shortfin makos, suggesting

38 that indices were less affected by unreported discarding. CPUE indices and landings of both

39 shark species have increased in recent years, suggesting increased importance as target species.

40 Analysis of logbook data resulted in unreliable indicators of shark abundance, but when trends

41 were interpreted in conjunction with landings data, disaggregated by area and month, and with

42 foreknowledge of market demand and regulation changes, anomalies could be explained. 


\section{Introduction}

44 Catch-per-unit effort (CPUE) trends based on fisher logbooks and landings data are widely used

in fisheries research to estimate the relative abundance of fished stocks. The key assumption that abundance is proportional to CPUE is rarely met, however, because the relationship is affected by intrinsic catchability fluctuations of fished stocks, and also by variability in fishing methods used and gear characteristics. Maunder and Punt (2004) reviewed methods to standardize catch and effort data to account for the added variability in inter-annual CPUE trends. Apart from variability that can be addressed within a standardization framework, underreporting of catches will affect the data from which abundance indices are derived (Groeneveld, 2003; Rudd and Branch, 2017; van Beveren et al., 2017). For example, unwanted sharks that are discarded overboard by pelagic longliners targeting mainly tunas and swordfish are infrequently reported in logbooks, and landing statistics therefore underrepresent the actual numbers of sharks caught during a fishing trip (Campana, 2016).

Standardized CPUE trends nevertheless remain an important relative measure of the abundance of sharks caught by pelagic longline gear in oceanic habitats. They are used by tuna Regional Fisheries Management Organizations (tRFMOs), such as the Indian Ocean Tuna Commission (IOTC) and the International Commission for the Conservation of Atlantic Tunas (ICCAT) to assess the status of sharks caught as a bycatch of tunas and swordfish (Francis et al., 2001; Su et al., 2008; Petersen et al., 2009; Cortés, 2013; ICCAT, 2016; IOTC, 2016). Some studies have used auxiliary information collected by fisheries observers at sea to assess discards (Cortés, 2013) but despite these efforts, most shark abundance indices retain high uncertainty. 
64 Pelagic sharks are vulnerable to fishing pressure, because of their life history traits and behaviour

65 patterns (Dulvy et al., 2008). As a group, they have lower productivity than teleosts, are long-

66 lived and slow-growing, and produce few offspring which mature late (Musick, 1999). Pelagic

67 sharks are predatory animals, and some species are found in association with other target species

68 of longline gear, on which they prey or compete with for food (Mejuto et al., 2008). Inevitably,

69 these sharks are caught in large numbers in areas of intensive longline fishing (Campana, 2016).

70 Pelagic sharks migrate freely and widely over their range, often across international boundaries

71 (Kohler et al., 2002; Block et al., 2011, Campana, 2016), thus making them vulnerable to high

72 seas fishing fleets.

73 Whether a captured shark will be discarded or retained and processed depends primarily on

74 species, as a proxy for economic value, and the regulatory environment within which a fishery

75 operates (James et al., 2016). Commonly retained sharks with high quality meat and marketable

76 fins include shortfin makos Isurus oxyrinchus, whereas blue sharks Prionace glauca are less

77 valuable, and are more often discarded. Blue sharks dominate the bycatch of pelagic longline

78 fisheries in subtropical and temperate waters worldwide (Oliver et al., 2015), and exceed the

79 catches of tuna and swordfish target species in some areas (Campana et al., 2009). They are

80 faster-growing and relatively more productive than most other shark species, and considered less

81 vulnerable to fishing pressure (Aires-da-Silva and Gallucci, 2007). Shortfin makos make up a

82 large proportion of retained bycatch of longline fisheries, and sometimes form the target of

83 shark-directed fisheries (Francis et al., 2001; Campana et al., 2005; Petersen et al., 2009;

84 Bustamante and Bennett, 2013). Makos are characterized by low population growth rates, and

85 are more vulnerable to overfishing than blue sharks (Dulvy et al., 2008). 
86 Neither species is considered to be in imminent danger of collapse, although populations of one

87 or both might be overexploited (Campana et al., 2005; Campana, 2016). Reported catches of blue

88 sharks in the Indian Ocean have continued to increase since the early 1990s (IOTC, 2016),

89 although catch rate estimates are highly uncertain, and probably represent only the sharks that

90 were retained onboard. North Atlantic stocks of shortfin makos appear to be overfished and

91 undergoing overfishing, whereas the status of South Atlantic stocks are highly uncertain

92 (ICCAT, 2017a, 2017b). The abundance of shortfin makos in the Indian ocean appear to have

93 increased in recent years (Kimoti et al., 2011, Coelho et al., 2013), but data may have been

94 affected by changes in reporting practices, rendering estimates unsure (Hoyle et al., 2017).

95 Overall, shark landings reported to the FAO peaked in 2003, and in the decade since then have

96 declined by almost $20 \%$ - a reflection of overfishing, rather than good management (Davidson et

97 al., 2016).

Both distant-water pelagic longline fleets and local vessels fish for tunas, swordfish and

99 sometimes sharks around southern Africa, where the Southeast (SE) Atlantic and the Southwest

100 (SW) Indian Oceans meet (Petersen et al., 2009; da Silva et al., 2015). Early local longline

101 fisheries for tunas (1960s) and sharks (since 1992) in South African waters met with varied

102 success (BCLME, 2005; Petersen and Goren, 2007). Japanese and Korean flagged vessels were

103 licensed to fish in South African waters from the early 1990s, where they set deep longline gear

104 to target tunas (Petersen and Goren, 2007). Thirty experimental tuna permits were issued to

105 South African-flagged vessels in 1997, and the local fishery was formalized in 2005, when long-

106 term fishing rights were issued respectively for swordfish- and tuna-directed fisheries, and the

107 shark-directed permits were abolished. Sharks continued to be targeted by some local vessels 
108 under a permit exemption, but their licenses were fully amalgamated into the tuna and swordfish

109 fishery in 2011 (da Silva et al., 2015), whereafter sharks were considered as a bycatch.

110 Petersen et al. (2009) reported that blue sharks and shortfin makos were the most common sharks

111 caught in longline gear set around southern Africa, and that local swordfish-directed vessels

112 caught more sharks than foreign vessels. Based on data collected by independent observers

113 onboard vessels, they observed declining abundance of both shark species between 2002 and

114 2007, accompanied by a decline in average shark size. Data collected by fisheries observers at

115 sea are rarely available for long uninterrupted periods, and therefore long-term indices of

116 abundance must often rely on logbook and landings data - even though these data may be

117 affected by targeting practices and under-reporting.

118 Campana (2016) highlighted the risks associated with ineffective fisheries management

119 structures, unmonitored fishing mortality (particularly of discarded sharks), and the scarcity of

120 basic information on the status of shark populations. Importantly, species-specific patterns and

121 information gaps, by ocean region and individual fishery, have been identified as critical

122 weaknesses in terms of global conservation and improved fisheries management efforts (Oliver

123 et al., 2015). We used logbook data collected from local and foreign pelagic longline fleets

124 between 2000 and 2015 to construct standardized CPUE trends of blue sharks and shortfin

125 makos reported in four fishing areas straddling the ICCAT and IOTC reporting regions. Official

126 landing statistics and auxiliary information on reporting practices, changes in the regulatory

127 environment and market demand were superimposed on the CPUE trends, to test hypotheses that

128 they would coincide with abrupt changes in the CPUE indices. Our study provides a reference

129 framework for the analysis and interpretation of commercial logbook data affected by unreported

130 discards - often the only source of information that fisheries researchers have for assessments. 


\section{Materials and methods}

132 2.1. Study area

133 The study was undertaken in the SE Atlantic and SW Indian Oceans, adjacent to the coast of

134 South Africa. Longlines set within the Exclusive Economic Zone (EEZ, within 200 nautical from

135 the shore) and in the surrounding high seas were included. The study area straddled the ICCAT

136 (west of $20^{\circ} \mathrm{E}$ ) and IOTC (east of $20^{\circ} \mathrm{E}$ ) reporting regions (Fig. 1). The ICCAT region along the

137 west coast of southern Africa is dominated by cool-temperate waters and productive upwelling

138 systems of the northwards flowing Benguela Current (Hutchings et al., 2009). The IOTC region

139 along the east coast is influenced by the western boundary Agulhas Current, which brings

140 warmer, less-productive subtropical waters southwestwards (Lutjeharms, 2006a, b; Beal et al.,

141 2011). The boundary zone between the two systems off the southern tip of Africa is highly

142 dynamic, influenced by current strength and direction, bottom topography, seasonality and

143 climatic events (Swart and Largier, 1987).

144 The study area was stratified into four areas, to reflect the tRFMO boundary and incorporate

145 known oceanographic features, as follows: West (a cool temperate area influenced by the

146 Benguela Current, extending from the Namibian border to $33^{\circ} \mathrm{S}$ ); Southwest (a dynamic

147 boundary zone, which includes the western Agulhas Bank, between 33 and 20 ${ }^{\circ}$ ); South (the

148 lower Agulhas Current area, where the narrow shelf broadens towards the west to form the

149 eastern Agulhas Bank, between 20 and $26^{\circ} \mathrm{E}$ ); and East (subtropical waters influenced by the

150 upper Agulhas Current, from $26^{\circ} \mathrm{E}$ to the Mozambique border (Fig. 1). The four areas were

151 similar to those used in a previous study on pelagic shark bycatches (Petersen et al., 2009). 


\section{2.2. Data and assumptions}

153 Logbook records completed on a set-by-set (daily) basis were obtained from the Department of

154 Agriculture, Forestry and Fisheries (DAFF) for local South African-flagged vessels and foreign-

155 flagged vessels (mainly Japanese and Korean) licensed to fish for tunas in the South African

156 EEZ. All catches were landed in local ports, and logbook records of foreign vessels were

157 available for the 2000 to 2015 period, excluding 2006, when they did not fish in the region.

158 Records for local vessels were obtained for fishing sets targeted at tunas, swordfish and pelagic

159 sharks between 2000 and 2015. The data comprised of daily retained catches by species by

160 numbers, weight (after reconciling estimated weight at sea with landed weight in port), numbers

161 of hooks set, set and haul positions and times, target species, depth of sets and bait type, and

162 whether a fisheries observer was present or not.

163 The logbook data were cleaned by removing anomalous records in which setting positions, date,

164 depth, fishing effort (number of hooks), set durations or catch composition or quantities were

165 clearly incorrect or mismatched. Records with setting positions outside the SW Indian Ocean and

166 SE Atlantic were removed. Data selected for the study were dates between 2000 and 2015;

167 fishing effort of 310-3 800 hooks per line; a maximum of 801 blue or shortfin makos reported

168 per set; and fewer sharks (both species combined) than hooks per set. Spatio-temporally explicit

169 catch and fishing effort of 29018 individual sets remained ( $86 \%$ of initial records), and were

170 used for analyses. For the local fleet, $37 \%$ of 16810 sets by 61 vessels recorded no blue sharks

171 and $32 \%$ recorded no shortfin makos. For the foreign fleet of 49 vessels, no blue sharks were

172 reported in $29 \%$, and no makos in $40 \%$ of 12208 sets. 
173 We assumed that blue sharks and shortfin makos were correctly identified in logbooks - these

174 two species are commonly caught and relatively easy to identify. Longfin makos (Isurus paucus)

175 have rarely been reported from the sampling region (Reardon et al., 2006), and hence all makos

176 were assumed to be I. oxyrinchus. Other shark species made up only a small part of the retained

177 catch, and were mostly grouped in logbook records, as requiem sharks (mostly Carcharhinus

178 spp.), threshers (Alopias spp.), hammerheads (Sphyrna spp.) or as unidentified sharks.

179 2.3. Data analysis

180 Variability in blue shark and shortfin mako CPUE (numbers/1 000 hooks) by year, month,

181 vessel, fleet, and observer presence (Table 1) was explored using Generalized Linear Mixed

182 Models in the statistical software package R, version 3.3.2 (R Development Core Team, 2016).

183 The R-libraries "Ime4" (Bates et al., 2016) and "Imtest" (Hothorn et al., 2015) were used to run

184 the GLMM procedure. Models were constructed individually for blue sharks and shortfin makos

185 caught in each of the West, Southwest, South and East areas. The distribution of data among

186 treatment cells are shown in supplementary Table S1.

187 The large proportion of zeroes catches justified the use of the delta method for analysis

188 (Pennington, 1983; Maunder and Punt, 2004; Lauretta et al., 2016). In the first submodel, the

189 probability of a non-zero catch was modelled, based on presence/absence information, and

190 assuming a binomial error distribution. In the second submodel, the positive catch numbers were

191 modelled using a gamma continuous probability distribution. The gamma distribution was

192 chosen because the relationship between the logarithms of the mean and variance of non-zero

193 CPUE records was close to two (data highly dispersed) (McCullagh and Nelder, 1989; 
194 Stefansson, 1996), and the gamma provided better fits than inflated discrete distributions in

195 preliminary tests.

196 Final models were selected based on a stepwise approach, involving modelling combinations of

197 error structures, link functions and explanatory variables. The most parsimonious models were

198 selected based on the lowest value of the Bayesian Information Criterion (BIC), and visual

199 assessment of residual plots. Fixed and random effects models provided similar fits, and we

200 selected fixed effects for all variables, except for a random effect for vessel.

201 Standardized CPUE trends by species and year for each area were computed as the product of the

202 probability of catch (binomial model) and positive catch (gamma model) obtained from the

203 model coefficients. The expected values in the final models were the specific CPUE using year

204 as the fixed (main) effect, as this is the factor of interest with regard to abundance trends

205 (Maunder and Punt, 2004; Venables and Dichmont, 2004).

206 Error back-calculation and error propagation were calculated using the conservative procedures

207 recommended by Jørgensen and Pedersen (1998), Lindberg (2000) and Tellinghuisen (2001).

208 This included the back-transformation of coefficients and their errors from logarithmic and logit

209 scales to the observation scales, as well as the propagation of error in models where back-

210 transformed estimates from gamma and binomial models had to be multiplied.

211 Anomalies in the inter-annual CPUE indices were identified post hoc, as sudden increments in

212 their scale that could not plausibly be explained on biological or population dynamics grounds

213 alone. Spatio-temporal trends in shark landings, as well as published and anecdotal auxiliary

214 information on the history of the fishery, regulatory framework, and market demand were 
215 superimposed over the CPUE indices to evaluate the effects of changes in fishing practices on

216 the observed trends.

\section{3. Results}

218 3.1. Nominal trends in fishing effort, landings and shark species composition

219 Some 52 million hooks were deployed by 110 vessels between 2000 and 2015, 31 million by

220 foreign vessels targeting tuna and 21 million by local vessels targeting mostly swordfish and

221 tuna. The combined fishing effort was greatest in 2011, with a total of nearly 6 million hooks set

222 in that year (Fig. 2A). Foreign vessels deployed an average of $2.0 \pm 1.1$ million hooks per year,

223 compared to $1.3 \pm 0.4$ million by local vessels over the same period. The numbers of hooks set

224 by foreign vessels peaked between May and October each year, whereas local vessels fished

225 throughout the year, with marginally fewer hooks set in January and February than other months

226 (Fig. 2B). Foreign vessels ventured further southwards than local vessels, which tended to

227 remain within the EEZ (Fig.1).

228 Foreign fishing effort increased from 0.5 million hooks in 2001 to a maximum of 3.9 million in

229 2011, when 15 vessels were active; thereafter it declined to 0.8 million hooks set by four vessels

230 in 2015 (Fig. 2). Zero effort was recorded in 2006, when no foreign vessels were licensed to fish

231 for tunas in the South African EEZ. Local fishing effort increased gradually between 2004 and

232 2011, thereafter remaining stable at 1.5-1.9 million hooks set per year by 15-17 vessels up to 2332015.

234 Local vessels fished in all four areas, but in the East their range was limited to the northern half

235 of the area, near a landing site at Richards Bay (Fig. 1). Foreign vessels fished mainly in the SW 
236 Indian Ocean, with the bulk of all hooks set in the South (58\%) and East (33\%) areas, and the

237 remaining 9\% in the SE Atlantic. Foreign vessels set an average of $2493 \pm 597$ (SD) hooks per

238 line, compared to only $1282 \pm 250$ hooks per line used by local vessels.

239 The ratio of shark landings to total landings by weight (all species, including tunas, swordfish,

240 blue sharks and shortfin makos) remained $<0.2$ for both fleets between 2000 and 2003,

241 whereafter it increased sharply for the local fleet, to $>0.5$ in 2004 (Fig. 3). The local fleet ratio

242 remained relatively constant at this higher level up to 2013, and then increased to the highest

243 level on record $(>0.6)$ in 2014 and 2015. With few exceptions, the ratio of sharks caught by the

244 foreign fleet remained at or below 0.1 in all years.

245 A total of 681456 sharks (10 $070 \mathrm{t})$ were reported by local and foreign fleets combined between

2462000 and 2015. Blue sharks dominated shark landings by numbers $(\% \mathrm{~N}=58 \%)$ whereas

247 shortfin makos contributed most to landed weight $(\% \mathrm{~W}=59 \%)$. 'Other sharks' could not

248 confidently be resolved to species level in the landings, but they made up only $1 \% \mathrm{~N}$ and $3 \% \mathrm{~W}$.

249 Nearly 4000 sharks were not identified beyond 'Sharks nei' (not elsewhere included), 3500

250 were grouped as requiem sharks (including several similar-looking Carcharhinid species, but

251 excluding blue sharks), and neither thresher sharks (Alopias spp.) nor hammerheads (Sphyrna

252 spp.) were identified beyond genus level. Tope sharks (Galeorhinus galeus) (included with the

253 requiem shark group) were first identified in landings in 2011.

254 Local vessels contributed the bulk of all sharks landed, comprising 91\% N and 88\% W (Fig. 4).

255 By area, sharks were the most common group in landings by local vessels fishing in the

256 Southwest $(66 \% \mathrm{~W})$ and South $(79 \% \mathrm{~W})$ (Fig. 5). Only 32\% W of landings from the West were

257 sharks, but they were mostly small sharks, contributing $70 \% \mathrm{~N}$ of landings from that area. Local 
258 vessels fishing in the East landed mainly tunas and swordfish, and fewer sharks (21\% N; $14 \%$

259 W). Sharks contributed $<10 \% \mathrm{~W}$ of foreign vessel landings from the South and East (SW Indian

260 Ocean) and around 15\% W in the West and Southwest (SE Atlantic) (Fig. 5). Overall, sharks

261 contributed $52 \% \mathrm{~N}$ and $31 \% \mathrm{~W}$ of the combined landings reported by both fleets.

262 Blue sharks and shortfin makos dominated shark landings (Fig. 5). Prior to 2004, nearly all

263 landed blue sharks were reportedly caught in the West, but thereafter landings from the

264 Southwest and South became progressively more important, especially after 2010, when landings

265 increased substantially (Fig. 6). Blue shark landings peaked at nearly 80000 individuals in 2014,

266 when most sharks originated from the Southwest. A similar trend occurred in 2011 and 2015,

267 when blue shark landings were also elevated (> 50000 sharks/y).

268 Shortfin mako landings increased sharply in 2004 and 2005, with most sharks originating from

269 the South during that period (Fig. 6). Mako landings peaked in 2011 (nearly 30000 sharks), and

270 after a decline, peaked again in 2014 (27 000) and 2015 (38 000). The elevated landings in all

271 three years originated mainly from the Southwest and South areas, with much smaller landings

272 from the West and East.

273 3.2. CPUE standardization

274 The final GLMM's selected to model CPUE trends for blue sharks and shortfin makos for each

275 of the four areas included vessel as a random effect and year, month, fleet and the presence or

276 absence of an observer as fixed effects. These combinations consistently provided the best fits.

277 The estimates, standard errors and p-values of the binomial and gamma submodels for each area

278 are provided in supplementary tables (Tables S2-S5). 
279 For blue sharks, the fleet variable was significant in three of four binomial models and in three

280 gamma models. Based on the coefficients, blue sharks were present more frequently in sets made

281 by the foreign- than the local fleet, but when present, far greater numbers of blue sharks were

282 captured by local vessels. Observer was a significant factor in three of four binomial- and two

283 gamma models. Blue shark presence and numbers reported were consistently higher in the

284 absence of an observer, suggesting increased targeting when not observed. Month was a

285 significant factor in all binomial and gamma models, thus verifying that season affects the

286 availability of blue and shortfin makos.

287 For shortfin makos, fleet was a significant factor in one of four binomial models and in two

288 gamma models. Shortfin makos were encountered more often, and in higher numbers in sets

289 made by the local- than foreign fleet. The presence of an observer was significant in all four

290 binomial- and three of four gamma models for shortfin makos. As for blue sharks, shortfin mako

291 presence and numbers reported increased when an observer was absent.

292 Although not consistent, month was often significant in the binomial and gamma models for all

293 four areas, and in most cases the presence and numbers of shortfin makos increased over the

294 autumn and winter months (Tables S2-S5). For shortfin makos, the probability of encounter

295 (binomial) was higher during autumn and winter months, and the numbers per set (gamma) were

296 higher in two areas (Southwest and South) in all four seasons. No consistent seasonal trend was

297 apparent for blue sharks.

298 The standardized CPUE indices for blue sharks over the 16-year period differed substantially

299 between the four areas (Fig. 7). Prior to 2003, blue shark CPUE was low in all areas, but it

300 increased substantially in 2004 and 2005, relative to initial values. Comparatively larger 
301 increases occurred in 2011 (West), 2008-2014 (Southwest), 2008 and 2013 (South) and in 2011

302 and 2014-2015 (East). The CPUE indices were highly variable between years, especially in the

303 West, where the number of blue sharks / 1000 hooks increased from 4 in 2010 to 191 in 2011,

304 and decreased to 57 two years later, in 2013. Notably, the maximum index values of blue sharks

305 in the West and Southwest were an order of magnitude greater than in the South and East,

306 reflecting their numerical preponderance in landings from these areas (Fig. 6). By weight, blue

307 sharks were also relatively more important in landings, (compared to other species) in the West 308 and Southwest (Fig. 5).

309 In 2011 and 2012, the probability of encounter (binomial) and numbers per set (gamma) of blue

310 sharks in the West were much higher than in any other year, resulting in exceptionally high

311 peaks in the CPUE index. Blue sharks caught in the West and Southwest were mainly small

312 juveniles, whereas those caught in the other two areas were, on average, much larger and

313 heavier, with their size increasing in an eastwards direction (Fig. 8).

314 The standardized CPUE indices for shortfin makos were less variable than for blue sharks, with

315 maxima of around 9 sharks $/ 1000$ hooks in the West and Southwest, declining to $<2$ sharks $/ 1$

316000 hooks in the South and $<1$ sharks/1 000 hooks in the East (Fig. 7). Initial increases in

317 shortfin mako CPUE occurred in 2004 in the West, and in 2005 in the other three areas. The

318 standardized trend in the West increased continually from 2008 ( $<1$ shark/1 000 hooks) to 2015

319 (8 sharks/1 000 hooks), and in the Southwest a similar, but more variable, long-term increase

320 occurred between 2006 ( 2 sharks/1 000 hooks) and 2015 (9 sharks/1 000 hooks). The CPUE

321 indices in the South and East increased steeply in 2005, but then remained stable or even

322 declined between 2005 and 2015. 
323 For both shark species, the indices suggest a greater abundance in the SE Atlantic (West and

324 Southwest areas) than in the SW Indian Ocean (South and East areas) (Fig. 7). The indices

325 further suggest increasing abundance (or alternatively increasing retention rates) in the SE

326 Atlantic, compared to more stable abundance in the SW Indian Ocean after 2005. The large

327 fluctuations in year-on-year index values in blue sharks in the West suggests that discarding

328 takes place in some years, or that large numbers of small juveniles are sometimes encountered, 329 and retained.

\section{Discussion}

331 Blue sharks and shortfin makos made up the bulk of sharks landed by the local- and foreign

332 pelagic longline vessels in the present study. Data collected by observers stationed on vessels

333 fishing off southern Africa prior to 2006 also reported blue sharks and shortfin makos as

334 predominant bycatches (Petersen et al., 2009). Fleets from Brazil and Uruguay caught mainly

335 blue-, shortfin mako and porbeagle sharks in the South Atlantic (Hazin et al., 2008), and

336 Portuguese longliners caught mainly blue sharks as bycatch in the equatorial Atlantic, with

337 shortfin makos and other sharks also present (Coelho et al., 2012). Fleets in the NW Atlantic

338 (Campana et al., 2005, 2006; Cortés, 2013), NE Atlantic and Mediterranean (Megalofonou et al.,

339 2005; Mejuto et al., 2009), North Pacific (Walsh and Teo, 2012) and South Pacific (Francis et

340 al., 2001) also caught mainly blue sharks and varying quantities of shortfin makos. The

341 predominance of blue sharks and shortfin makos in the present study is therefore consistent with

342 trends from other studies.

343 Most shark landings made between 2000 and 2015 originated from local vessels $(91 \% \mathrm{~N}$;

$34488 \% \mathrm{~W})$. Proportionally, blue sharks and shortfin makos were more important in local than 
345 foreign landings in all four areas, and the combined ratio of shark to total landed weight

346 fluctuated around 0.5 for the local fleet, compared to 0.1 for the foreign fleet. Fishing method,

347 area fished and seasonality of fishing differed between the two fleets, and could partially explain

348 the disproportionate importance of sharks to them. Local vessels set hooks near the surface,

349 overnight, and with gear that included light-sticks and squid for bait. Although directed mainly at

350 swordfish, this configuration also contributes to high shark catch rates (Stone and Dixon, 2001;

351 dos Santos et al., 2002; Ward and Myers, 2005; Gilman et al., 2008; Mejuto et al., 2008; Petersen

352 et al., 2009). Foreign vessels that targeted tunas used a different gear configuration and set hooks

353 deeper and during daytime, thus avoiding high shark bycatches (Petersen et al., 2009). Local

354 vessels fished mostly in the highly productive SE Atlantic and in the transition zone over the

355 Agulhas Bank, where blue sharks and shortfin makos were more numerous (Petersen et al., 2009;

356 Groeneveld et al., 2014), whereas foreign vessels focussed on the tuna stocks in the SW Indian

357 Ocean.

358 Blue shark landings originated mostly from the SE Atlantic (West, Southwest) and the South, but

359 the CPUE index was low in the South, compared to the other two areas (see Fig. 7). Similarly, a

360 large proportion of shortfin mako landings originated from the South, but the CPUE index for

361 this area was considerably lower than in the West and Southwest. The anomaly of proportionally

362 high landings but low CPUE in the South was ascribed to an overlap in the fishing areas

363 frequented by local- and foreign vessels in the South. As a consequence, fishing effort in the

364 South was high, but not all of it contributed to shark landings - especially not foreign vessels.

365 The CPUE indices for blue sharks and shortfin makos caught in the South were thus artificially

366 reduced in the model outputs, relative to the Southwest and West areas, where foreign vessels

367 fished less intensively. 
368 The modelled maximum CPUE of 191 blue sharks/1000 hooks for the West in 2011 was

369 exceptionally high, compared to all other values. A combination of a high probability of

370 encountering blue sharks and large numbers of blue sharks caught per longline set can explain

371 this peak. Given the small size of blue sharks caught in the West (Fig. 8), we suggest that the

372 high index value reflects fishing in a blue shark nursery area, where small juveniles aggregate,

373 and can be caught in large numbers. The retention of large numbers of small juveniles in the

374 West in 2011, potentially as a result of high market demand in that year, can therefore explain

375 the comparatively high numerical index value. In contrast, discarding of blue sharks in other

376 years, without reporting them, would have depressed the index relative to the peak 2011 value,

377 when discarding was presumably reduced.

378 Coelho et al. (2018) suggested that the main nursery grounds for blue sharks in the South

379 Atlantic are in the temperate waters of the SE Atlantic, off western South Africa and Namibia.

380 Furthermore, da Silva et al. (2010) proposed a blue shark parturition and nursery area in the

381 Benguela / Agulhas Current confluence, based on a high frequency of small juveniles in research

382 longline catches. These putative nursery areas overlap the West and Southwest areas of the

383 present study, and we are therefore confident that the high CPUE index value in 2011 in the

384 West is not unrealistic. Rather, it is indicative of increased retention of small blue sharks caught

385 in nursery areas in some years.

386 Shortfin makos have a higher economic value than blue sharks (Dent and Clarke, 2015), and

387 their CPUE indices are therefore less likely to be affected by discards than in the case of blue

388 sharks. Inter-annual fluctuations are thus smaller, and potentially reflect variations in shortfin

389 mako abundance better. Nevertheless, increased targeting and retention undoubtedly played a

390 major role in 2004 and 2005, when shortfin mako CPUE indices first increased substantially. We 
391 suggest that the continued increase in the West (after 2008) and Southwest (after 2006) reflected

392 increased targeting by local vessels, possibly combined with higher abundance. Shortfin mako

393 landings reported to ICCAT by the local longline fleet increased sharply from $250 \mathrm{t}$ in 2013 , to

$394476 \mathrm{t}$ in 2014 , and to $613 \mathrm{t}$ in 2015 , thus highlighting their growing importance on markets.

395 CPUE indices of other fleets in the SE Atlantic that report to ICCAT also suggested a relative

396 increase in shortfin mako abundance, particularly since 2004, although estimates were highly

397 variable between years and fleets (ICCAT, 2017b). Japanese and Portuguese longline fleets in

398 the Indian Ocean have reported increasing shortfin mako abundance in recent years (Kimoti et

399 al., 2011; Coelho et al., 2013), but trends may have been affected by changes in reporting

400 practices (Hoyle et al., 2017).

401 Most shortfin mako landings originated from the Southwest (SE Atlantic) and South (SW Indian

402 Ocean) areas, at the confluence of the Benguela and Agulhas Current systems, suggesting that

403 they are more abundant there than in the East. Groeneveld et al. (2014) found fewer, but larger-

404 sized shortfin makos in the East area, with mean shark size declining from east to west. The

405 smallest individuals, in larger numbers, occurred near the Agulhas Bank edge (South and

406 Southwest areas in the present study) in June to November, suggesting that juveniles congregate

407 there to feed. A juvenile feeding ground at the Agulhas Bank edge could therefore explain why

408 the majority of shortfin mako landings originate from the South and Southwest areas, and also

409 why the CPUE index reached its highest levels in the Southwest.

410 The market price for shortfin makos increased between 2003 and 2004 (Dent and Clarke, 2015;

411 Autoridad_Portuaria_de_Vigo 2016), whereafter local vessels increasingly targeted shortfin

412 makos, as seen from sharply increasing CPUE indices in all areas during that period. Reported

413 shortfin mako landings increased ten-fold between 2003 and 2005, with most of the sharks 
414 originating from expanded fishing grounds over the Agulhas Bank (South area), where shortfin

415 makos are more abundant (Smith, 2005).

416 Apart from increased targeting, we suggest that sudden increases in CPUE indices of both

417 species may have resulted from substantive changes made to fishing regulations and their

418 enforcement (da Silva et al. 2015; Table 2). Weak enforcement and under-reporting by local

419 shark-directed vessels active prior to 2004 resulted in implausibly low CPUE indices at that time.

420 Large-scale finning and discarding of carcasses in 2000 and 2001 (25-30\% of blue sharks) were

421 reported (Petersen and Goren, 2007) and landings were not reported to the IOTC in 2001 and

4222002 (IOTC, 2004). Permits for shark-directed longliners were abolished in 2005, and formerly

423 shark-directed vessels were allocated permits to catch swordfish and tunas (da Silva et al. 2015),

424 within a stricter regulatory framework. Some vessels continued to land sharks under an

425 exemption, however, but the sudden increase in CPUE indices in 2003-2005, and continued

426 higher index levels thereafter in most cases, most likely demonstrates improved landings and

427 reporting after 2004 (Smith, 2005).

428 Shark-directed vessels fishing under exemption permits were fully amalgamated into the tuna 429 and swordfish fisheries in 2011, whereafter shark landings were managed as a bycatch of the 430 pelagic longline fishery (West and Smith, 2012). A precautionary upper catch limit of 2000 431 tonnes dressed weight per year was imposed in 2012 (West and Smith, 2013; Anderson et al., 432 2015) and shark fins had to be accompanied by trunks, with the total weight of retained fins not 433 exceeding $8 \%$ of shortfin mako- or $13 \%$ of blue sharks landed weight, respectively (West and 434 Smith, 2013). Increases in the CPUE indices of both species after 2010 suggest that reporting 435 improved after the imposition of new regulations, but the upwards trends in both shortfin mako 
436 CPUE and blue shark indices over the past decade, mainly in the West and Southwest, indicate a

437 continued, and potentially increasing reliance of local pelagic longliners on shark landings.

\section{Conclusion}

439 The key assumption that CPUE is proportional to abundance was not met in this study, because

440 the modelling framework could not reconcile the influences of inconsistent reporting and

441 targeting on the long-term data. The CPUE indices based on logbook data were unreliable

442 indicators of shark abundance, but when interpreted in conjunction with reported landings, by

443 area and season, and with foreknowledge of market trends and regulation changes, anomalies in

444 the indices could be plausibly explained. The scale of CPUE increments, up to an order of

445 magnitude on a year-on-year basis, demonstrated marked effects of inconsistent reporting and

446 targeting, driven by market value and changes in regulations. The upwards trend in shortfin

447 mako CPUE indices over the last years of the time series suggested that they are increasingly

448 being targeted and retained. Our study provides a reference framework for the analysis and

449 interpretation of commercial logbook data influenced by factors external to stock abundance -

450 often the only source of information that fisheries researchers have for assessments.

\section{Acknowledgements}

452 We thank CapFish, particularly Victor Ngcongo and Willem Louw, for their advice on how the 453 pelagic longline fishing fleet operates, and the skippers of the longline vessels for providing

454 insight into various fishing strategies and techniques. Thanks are due to the Department of

455 Agriculture, Forestry and Fisheries, particularly Charlene da Silva and Wendy West, for 456 providing the landings and logbook data for the study, and for their advice. 


\section{References}

459

460

461

462

463

464

465

466

467

468

469

470

471

472

473

474

475

476

477

478

479

480

Aires-da-Silva AM, Gallucci VF. 2007. Demographic and risk analyses applied to management and conservation of the blue shark (Prionace glauca) in the North Atlantic Ocean. Marine and Freshwater Research 58 (6): 570-580.

Anderson R, Auerswald L, Butterworth D, Cockcroft A, Coetzee J, da Silva C, Durholtz D, Fairweather T, Geja Y, Githaiga-Mwicigi J, Kemp D, Kerwath S, Lamberth S, Leslie R, Mackenzie A, Maharaj G, Mbande S, Prochazka K, Rothman M, Singh L, Twatwa N, Van der Lingen C, West W. 2015. Status of the South African Marine Fishery Resources 2014. Department of Agriculture, Forestry and Fisheries. Cape Town, South Africa.

Autoridad_Portuaria_de_Vigo. 2016. Puerto de Vigo - Annual Reports (2003 - 2015). Available at http://www.apvigo.com/control.php?sph=a_iap $=1251 \% \%$ p_rpp $=1 \% \%$ s_idm $=3$ [accessed 2018/01/08].

Bates D, Maechler M, Bolker B, Walker S, Christensen RHB, Singmann H, Dai B, Grothendieck G, Green P, Bolker MB. 2016. Linear Mixed-Effects Models using 'Eigen' and S4: Package 'Ime4'. CRAN Repository.

BCLME (Benguela Current Large Marine Ecosystem). 2005. Ecosystem Approach to Fishery Management: South Africa Large Pelagics TROM Review. Available at http://www.bclme.org/projects/docs/LMR-EAF-03-01.pdf.

Beal LM, De Ruijter WPM, Biastoch A, Zahn R. 2011. On the role of the Agulhas system in ocean circulation and climate. Nature 472 (7344): 429-436.

Block BA, Jonsen ID, Jorgensen SJ, Winship AJ, Shaffer SA, Bograd SJ, Hazen EL, Foley DG, Breed G, Harrison A. 2011. Tracking apex marine predator movements in a dynamic ocean. Nature 475 (7354): 86. 
481 Bustamante C, Bennett MB. 2013. Insights into the reproductive biology and fisheries of two

482

483

484

485

486

487

488

489

490

491

492

493

494

495

496

497

498

499

500

501

502

503

504

505

506 commercially exploited species, shortfin mako (Isurus oxyrinchus) and blue shark (Prionace glauca), in the south-east Pacific Ocean. Fisheries Research 143 (0): 174-183.

Camhi MD, Valenti SV, Fordham SV, Fowler SL, Gibson C. 2009. The conservation status of pelagic sharks and rays: report of the IUCN shark specialist group pelagic shark red list workshop. IUCN Species Survival Commission Shark Specialist Group. Newbury, UK. $x+78 p$.

Campana SE, Marks L, Joyce W. 2005. The biology and fishery of shortfin mako sharks (Isurus oxyrinchus) in Atlantic Canadian waters. Fisheries Research 73 (3): 341-352.

Campana SE, Brazner J, Marks L. 2006. Assessment of the Recovery Potential of Shortfin Mako Sharks in Atlantic Canada. Population Ecology Division, Bedford Institute of Oceanography Darmouth, Canada.

Campana SE, Joyce W, Manning MJ. 2009. Bycatch and discard mortality in commercially caught blue sharks Prionace glauca assessed using archival satellite pop-up tags. Marine Ecology Progress Series 387: 241-253.

Campana SE. 2016. Transboundary movements, unmonitored fishing mortality, and ineffective international fisheries management pose risks for pelagic sharks in the Northwest Atlantic. Canadian journal of fisheries and aquatic sciences 73 (10): 1599-1607.

Clarke DT, Smith C. 2008. National Report of South Africa. Indian Ocean Tuna Commission. Report No. IOTC-2008-SC-INF17. Cape Town, South Africa.

Coelho R, Santos MN, Amorim S. 2012. Effects of hook and bait on targeted and bycatch fishes in an Equatorial Atlantic pelagic longline fishery. Bulletin of Marine Science 88 (3): 449467.

Coelho R, Infante P, Santos MN. 2013. Application of Generalized Linear Models and Generalized Estimation Equations to model at-haulback mortality of blue sharks captured in a pelagic longline fishery in the Atlantic Ocean. Fisheries Research 145 (0): 66-75.

Peer] reviewing PDF | (2017:10:21432:2:0:CHECK 3 Aug 2018) 
507 Coelho R, Mejuto J, Domingo A, Yokawa K, Liu KM, Cortés E, Romanov EV, da Silva C, 508 Hazin F, Arocha F, Mwilima AM. 2018. Distribution patterns and population structure of 509 the blue shark (Prionace glauca) in the Atlantic and Indian Oceans. Fish and Fisheries

511 Cortés E. 2013. Standardized catch rates of mako sharks from the US pelagic longline logbook and observer programs using a generalized linear mixed model. Collect. Vol. Sci. Pap. ICCAT 69 (4): 1578-1590.

514

515

516

517

518

519

520

521

522 523

524 525

526

527

528

529

530

531

532 da Silva C, Kerwath S, Wilke C, Meyer M, Lamberth S. 2010. First documented southern transatlantic migration of a blue shark Prionace glauca tagged off South Africa. African Journal of Marine Science 32 (3): 639-642.

da Silva C, Booth AJ, Dudley SFJ, Kerwath SE, Lamberth SJ, Leslie RW, McCord ME, Sauer WHH, Zweig T. 2015. The current status and management of South Africa's chondrichthyan fisheries. African Journal of Marine Science 37 (2): 233-248.

Davidson LN, Krawchuk MA, Dulvy NK. 2016. Why have global shark and ray landings declined: improved management or overfishing? Fish and Fisheries 17 (2): 438-458.

Dent F, Clarke S. 2015. State of the global market for shark products. FAO Fisheries and Aquaculture technical paper, (590), p.I.

dos Santos MN, Garcia A, Pereira JG. 2002. A historical review of the by-catch from the Portuguese surface long-line swordfish fishery: observations on blue shark (Prionace glauca) and short-fin mako (Isurus oxyrinchus). ICCAT Collective Volume of Scientific Papers 54: 1333-1340.

Dulvy NK, Baum JK, Clarke S, Compagno LJV, Cortés E, Domingo A, Fordham S, Fowler S, Francis MP, Gibson C, Martínez J, Musick JA, Soldo A, Stevens JD, Valenti S. 2008. You can swim but you can't hide: the global status and conservation of oceanic pelagic sharks and rays. Aquatic Conservation: Marine and Freshwater Ecosystems 18 (5): 459482. 
533 Francis MP, Griggs LH, Baird SJ. 2001. Pelagic shark bycatch in the New Zealand tuna longline fishery. Marine and Freshwater Research 52 (2): 165-178.

535

536

537

538

539

540

541

542

543

544

545

546

547

548

549

550

551

552

553

554

555

556

557

558

Gilman E, Clarke S, Brothers N, Alfaro-Shigueto J, Mandelman J, Mangel J, Petersen S, Piovano S, Thomson N, Dalzell P, Donoso M, Goren M, Werner T. 2008. Shark interactions in pelagic longline fisheries. Marine Policy 32 (1): 1-18.

Groeneveld JC. 2003. Under-reporting of catches of South Coast rock lobster Palinurus gilchristi, with implications for the assessment and management of the fishery. African Journal of Marine Science 25: 407-411.

Groeneveld JC, Cliff G, Dudley S, Foulis A, Santos J, Wintner S. 2014. Population structure and biology of shortfin mako, Isurus oxyrinchus, in the south-west Indian Ocean. Marine and Freshwater Research 65 (12): 1045-1058.

Hazin FH, Broadhurst MK, Amorim AF, Arfelli CA, Domingo A. 2008. Catches of pelagic sharks by subsurface longline fisheries in the South Atlantic Ocean during the last century: A review of available data with emphasis on Uruguay and Brazil. In: Camhi MD, Pikitch EK, Babcock EA (eds.), Sharks of the Open Ocean: Biology, Fisheries and Conservation. Oxford, UK: Blackwell Publishing Ltd. pp. 213-229.

Hothorn T, Zeileis A, Farebrother RW, Cummins C, Millo G, Mitchell D, Zeileis MA. 2015. Testing Linear Regression Models: Package 'Imtest'. CRAN.

Hoyle SD, Semba Y, Kai M, Okamoto H. 2017. Development of Southern Hemisphere porbeagle shark stock abundance indicators using Japanese commercial and survey data. New Zealand Fisheries Assessment Report 2017/07. WCPFC Scientific Committee 13th regular session WCPFC-SC13-SA-IP-15: 64.

Hutchings L, van der Lingen CD, Shannon LJ, Crawford RJM, Verheye HMS, Bartholomae CH, van der Plas AK, Louw D, Kreiner A, Ostrowski M, Fidel Q, Barlow RG, Lamont T, Coetzee J, Shillington F, Veitch J, Currie JC, Monteiro PMS. 2009. The Benguela Current: An ecosystem of four components. Progress in Oceanography 83 (1-4): 15-32. 
559

560

561

562

563

564

565

566

567

568

569

570

571

572

573

574

575

576

577

578

ICCAT. 2016. Report for biennial period, 2014-15 Part II (2015) - Vol. 1 International Commission for the Conservation of Atlantic Tunas. Madrid, Spain.

ICCAT 2017a. Report of the2017 ICCAT shortfin mako assessment meeting. International Commission for the Conservation of Atlantic Tunas. Madrid, Spain. https://www.iccat.int/Documents/Meetings/Docs/2017_SMA_ASS_REP_ENG.pdf

ICCAT. 2017b. Report of the 2017 ICCAT shortfin mako data preparatory meeting. International Commission for the Conservation of Atlantic Tunas. Madrid, Spain. https://www.iccat.int/Documents/Meetings/Docs/2017_SMA_DATA_PREP_ENG.pdf

IOTC. 2004. South Africa National Report. Indian Ocean Tuna Commission. Department of Agriculture, Forestry and Fisheries. Cape Town, South Africa. Report No. IOTC-2004SC-INF06. Mahe, Seychelles.

IOTC. 2016. Report of the 19th Session of the IOTC Scientific Committee. Report No. IOTC2016-SC19-R[E]. Seychelles, 1-5 December 2016.

James KC, Lewison RL, Dillingham PW, Curtis KA, Moore JE. 2016. Drivers of retention and discards of elasmobranch non-target catch. Environmental Conservation 43 (1): 3-12.

Jørgensen E, Pedersen AR. 1998. How to obtain those nasty standard errors from transformed data - and why they should not be used. Department of Biometry and Informatics, Danish Institute of Agricultural Science. Tjele, Denmark.

Kimoti A, Hiraoka Y, Ando T, Yokawa K. 2011. Standardized CPUE of shortfin mako shark (Isurus oxyrinchus) caught by Japanese longliners in the Indian Ocean in the period between 1994 and 2010. IOTCWPEB07-34. 8pp.

Kohler NE, Turner PA, Hoey JJ, Natanson LJ, Briggs R. 2002. Tag and recapture data for three pelagic shark species: blue shark (Prionace glauca), shortfin mako (Isurus oxyrinchus), and porbeagle (Lamna nasus) in the North Atlantic Ocean. Collective Volume of Scientific Papers - ICCAT 54 (4): 1231-1260. 
584 Lauretta MV, Walter JF, Christman MC. 2016. Some considerations for CPUE standardization; 585 variance estimation and distributional considerations. Collective Volume of Scientific 586 Papers - ICCAT 72 (9): 2304-2312.

587 Lindberg V. 2000. Manual on Uncertainties, Graphing and the Vernier Caliper, Part I: 588 Uncertainties and error propagation. Rochester Institute of Technology. New York, 589 USA.

Lutjeharms J. 2006a. The Agulhas Current. New York: Springer.

591 592

593 594

595 596

597

Lutjeharms JRE. 2006b. The Coastal Oceans of South-Eastern Africa (15,W). In: Robinson AR, Brink KH (eds.), The Sea. Cambridge: Harvard University Press. pp. 783-834.

Maunder MN, Punt AE. 2004. Standardizing catch and effort data: a review of recent approaches. Fisheries Research 70 (2-3): 141-159.

McCullagh P, Nelder JA. 1989. Generalized Linear Models, no. 37 in Monograph on Statistics and Applied Probability. Chapman \& Hall.

Megalofonou P. 2005. Incidental catch and estimated discards of pelagic sharks from the swordfish and tuna fisheries in the Mediterranean Sea. Fishery Bulletin 103 (4): 620-634.

Mejuto J, García-Cortés B, Ramos-Cartelle A. 2008. Trials using different hook and bait types in the configuration of the surface longline gear used by the Spanish swordfish (Xiphias gladius) fishery in the Atlantic Ocean. Collect. Vol. Sci. Pap. ICCAT 62 (6): 1793-1830.

Mejuto J, García-Cortés B, Ramos-Cartelle A, De la Serna J. 2009. Scientific estimations of bycatch landed by the Spanish surface longline fleet targeting swordfish (Xiphias gladius) in the Atlantic Ocean with special reference to the years 2005 and 2006. Collect. Vol. Sci. Pap. ICCAT 64 (7): 2455-2468.

Musick JA. 1999. Criteria to define extinction risk in marine fishes: the American Fisheries Society initiative. Fisheries 24 (12): 6-14. 
608 Oliver S, Braccini M, Newman SJ, Harvey ES. 2015. Global patterns in the bycatch of sharks $609 \quad$ and rays. Marine Policy 54: 86-97.

610 Pennington M. 1983. Efficient estimators of abundance, for fish and plankton surveys. Biometrics 39 (1): 281-286.

612 Petersen S, Goren M. 2007. South Africa Pelagic longline tuna and swordfish fishery: Industry

613

614

615

616

617

618

619

620

621

622

623

624

625

626

627

628

629

630

631 practices and attitudes towards shark depredation and unwanted bycatch. In: Gilman E, Clarke S, Brothers N, Alfaro-Shigueto-J., Mandelman J, Mangel J, Petersen S, Piovano S, Thomson N, Dalzell P, et al. (eds.). Shark Depredation and Unwanted Bycatch in Pelagic Longline Fisheries: Industry Practices and Attitudes, and Shark Avoidance Strategies. Honolulu, U.S.A.: Western Pacific Regional Fishery Management Council.

Petersen S, Honig M, Ryan P, Underhill L, Compagno LJ. 2009. Pelagic shark bycatch in the tuna-and swordfish-directed longline fishery off southern Africa. African Journal of Marine Science 31 (2): 215-225.

R_Development_Core_Team. 2016. R: A language and environment for statistical computing. Vienna, Austria.: R Foundation for Statistical Computing.

Reardon MB., Gerber L, Cavanagh RD. 2006. Isurus paucus. The IUCN Red List of Threatened Species 2006: e.T60225A12328101. http://dx.doi.org/10.2305/IUCN.UK.2006.RLTS. T60225A12328101.en. Downloaded on 18 October 2017.

Rudd, M.B. and Branch, T.A., 2017. Does unreported catch lead to overfishing? Fish and Fisheries, 18(2), pp.313-323.

Smith C. 2005. National Report of South Africa. Indian Ocean Tuna Commission. Department of Agriculture, Forestry and Fisheries. Cape Town, South Africa.

Stefánsson G. 1996. Analysis of groundfish survey abundance data: combining the GLM and delta approaches. ICES Journal of Marine Science 53 (3): 577-588. 
632 Stone HH, Dixon LK. 2001. A comparison of catches of swordfish, Xiphias gladius, and other

633

634

635

636

637

638

639

640

641

642

643

644

645

646

647

648

649

650

651

652

653

654

655

656 pelagic species from Canadian longline gear configured with alternating monofilament and multifilament nylon gangions. Fishery Bulletin 99 (1): 210-216.

Su N-J, Yeh S-Z, Sun C-L, Punt AE, Chen Y, Wang S-P. 2008. Standardizing catch and effort data of the Taiwanese distant-water longline fishery in the western and central Pacific Ocean for bigeye tuna, Thunnus obesus. Fisheries Research 90 (1): 235-246.

Swart VP, Largier JL, 1987. Thermal structure of Agulhas Bank water. South African Journal of Marine Science 5(1): 243-252.

Tellinghuisen J. 2001. Statistical error propagation. The Journal of Physical Chemistry A 105 (15): 3917-3921.

van Beveren, E., Duplisea, D., Castonguay, M., Doniol-Valcroze, T., Plourde, S. and Cadigan, N., 2017. How catch underreporting can bias stock assessment of and advice for northwest Atlantic mackerel and a possible resolution using censored catch. Fisheries Research 194: 146-154.

Venables WN, Dichmont CM. 2004. GLMs, GAMs and GLMMs: an overview of theory for applications in fisheries research. Fisheries Research 70: 319-337.

Walsh W, Teo S. 2012. Catch statistics, length data and standardized CPUE for blue shark Prionace glauca taken by longline fisheries based in Hawaii and California. NOAA Fisheries, Southwest Fisheries Science Center. Report No. ISC/12SHARKWG-1/02.

Ward P, Myers RA. 2005. Inferring the depth distribution of catchability for pelagic fishes and correcting for variations in the depth of longline fishing gear. Canadian Journal of Fisheries and Aquatic Sciences 62 (5): 1130-1142.

West W, Kerwath S. 2015a. South African National Report to the Scientific Committee of the Indian Ocean Tuna Commission, 2015. Department of Agriculture, Forestry and Fisheries. Report No. IOTC-2015-SC18-NR37. Cape Town, South Africa. 
657 West W, Kerwath S. 2015b. National Report of South Africa. Indian Ocean Tuna Commission. 658 Department of Agriculture, Forestry and Fisheries. Report No. IOTC-2015-SC16-NR33. 659 Cape Town, South Africa.

660 West W, Smith C. 2012. National Report of South Africa. Indian Ocean Tuna Commisison.

661 Department of Agriculture, Forestry and Fisheries. Report No. IOTC-2012-SC15-NR33.

662 Cape Town.

663

664

665

666

667

668

669

670

671

672

673

674

675

676

677

678

679

680

681
West W, Smith C. 2013. National Report of South Africa. Indian Ocean Tuna Commisison. Department of Agriculture, Forestry and Fisheries. Report No. IOTC-2013-SC16-NR33. Cape Town.

\section{Figure titles:}

Fig. 1. Geographical distribution of fishing effort by A) local and B) foreign pelagic longliners between 2000 and 2015, based on logbook data provided by vessel skippers. The sampling area is subdivided into the SE Atlantic (reporting to ICCAT) and the SW Indian Ocean (reporting to IOTC) along $20^{\circ} \mathrm{E}$, and the West, Southwest, South and East sampling areas are shown. Bubble size is proportional to the numbers of hooks set per line. CT $=$ Cape Town, PE $=$ Port Elizabeth, $\mathrm{EL}=$ East London, $\mathrm{DBN}=$ Durban, $\mathrm{RB}=$ Richards Bay

Fig. 2. Numbers of hooks set per A) year (2000-2015) and B) per calendar month, as reported by local and foreign pelagic longliners fishing in the study area.

Fig. 3. Ratio of shark landings (weight of blue and shortfin mako sharks combined) to total landings (all species, including tunas, swordfish, blue sharks and shortfin makos) between 2000 and 2015, for local and foreign pelagic longliners, respectively. 
682 Fig. 4. Cumulative weight of blue sharks and shortfin makos landed per year (2000-2015) by 683 local and foreign pelagic longliners, respectively.

684

685 Fig. 5. Relative weights of landed target species (tunas and swordfish), blue sharks, shortfin 686 makos and sharks 'nei' (not elsewhere included) per area by A) local and B) foreign pelagic 687 longliners, respectively. Sharks nei included thresher, hammerhead, requiem, and unidentified 688 sharks.

689

690 Fig. 6. Cumulative numbers of A) blue sharks and B) shortfin makos reported in logbooks per 691 area, between 2000 and 2015.

692

693 Fig. 7. Standardized CPUE indices $( \pm$ SE) for blue sharks and shortfin makos in the A) West, B) 694 Southwest, C) South and D) East areas, based on the binomial and gamma models applied in the 695 study.

696

697 Fig. 8. Average weight (kg) of individual blue sharks caught in each area in 2011, and for all 698 years combined $( \pm \mathrm{SE})$. Total number of sharks $(n)$ is included in the bars. 


\section{Figure 1}

Geographical distribution of fishing effort by A) local and B) foreign pelagic longliners between 2000 and 2015, based on logbook data provided by vessel skippers.

The sampling area is subdivided into the SE Atlantic (reporting to ICCAT) and the SW Indian Ocean (reporting to IOTC) along $20^{\circ} \mathrm{E}$, and the West, Southwest, South and East sampling areas are shown. Bubble size is proportional to the numbers of hooks set per line. $C T=$ Cape Town, $\mathrm{PE}=$ Port Elizabeth, $\mathrm{EL}=$ East London, $\mathrm{DBN}=$ Durban, $\mathrm{RB}=$ Richards Bay 


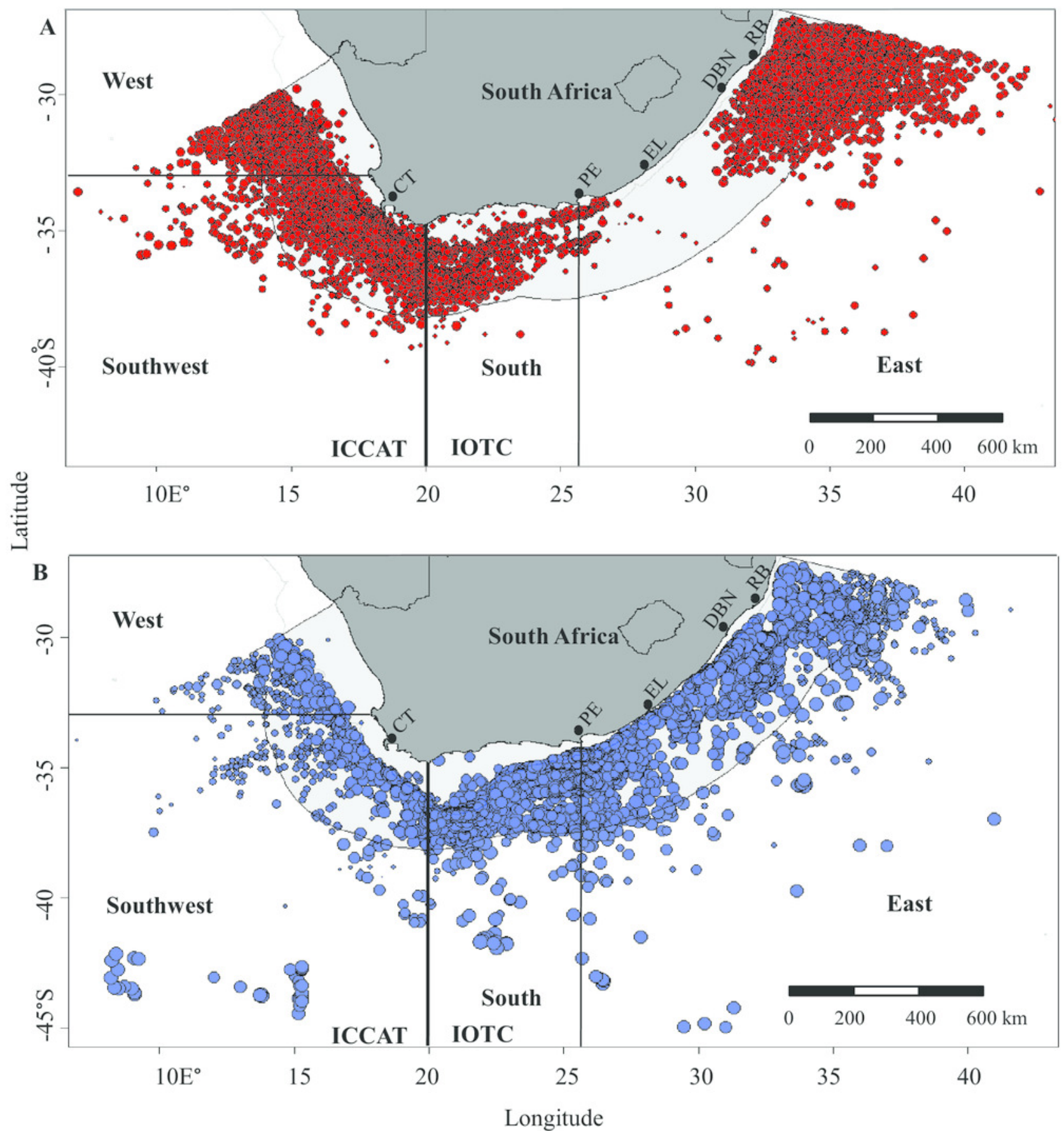


Figure 2

Numbers of hooks set per A) year (2000-2015) and B) per calendar month, as reported by local and foreign pelagic longliners fishing in the study area.

The distribution of the data by area and season is shown in supplementary Table S1. 

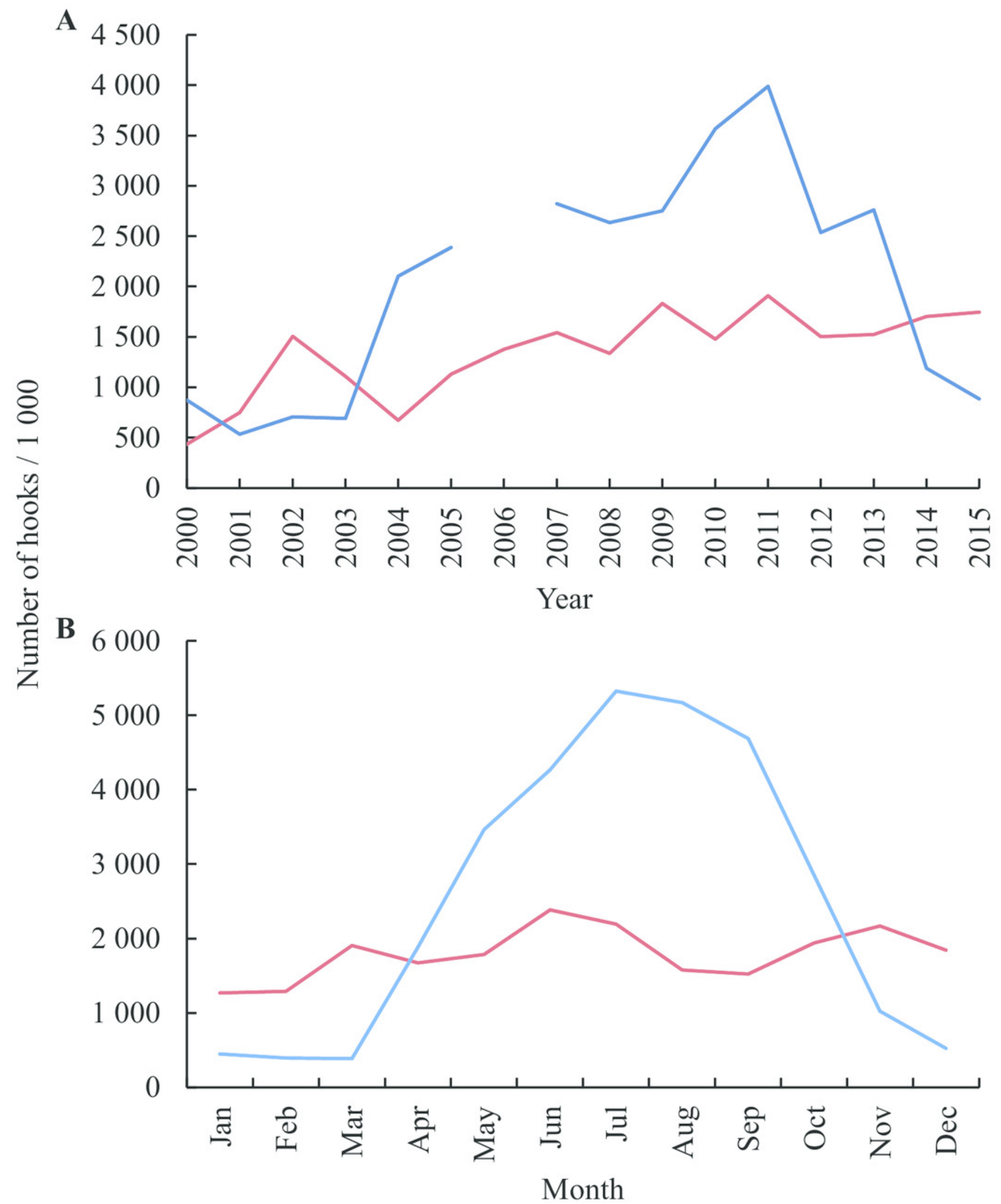
Figure 3

Ratio of shark landings (weight of blue and shortfin mako sharks combined) to total landings (all species, including tunas, swordfish, blue sharks and shortfin makos) between 2000 and 2015, for local and foreign pelagic longliners, respectively.




Figure 4

Cumulative weight of blue sharks and shortfin makos landed per year (2000-2015) by local and foreign pelagic longliners, respectively.

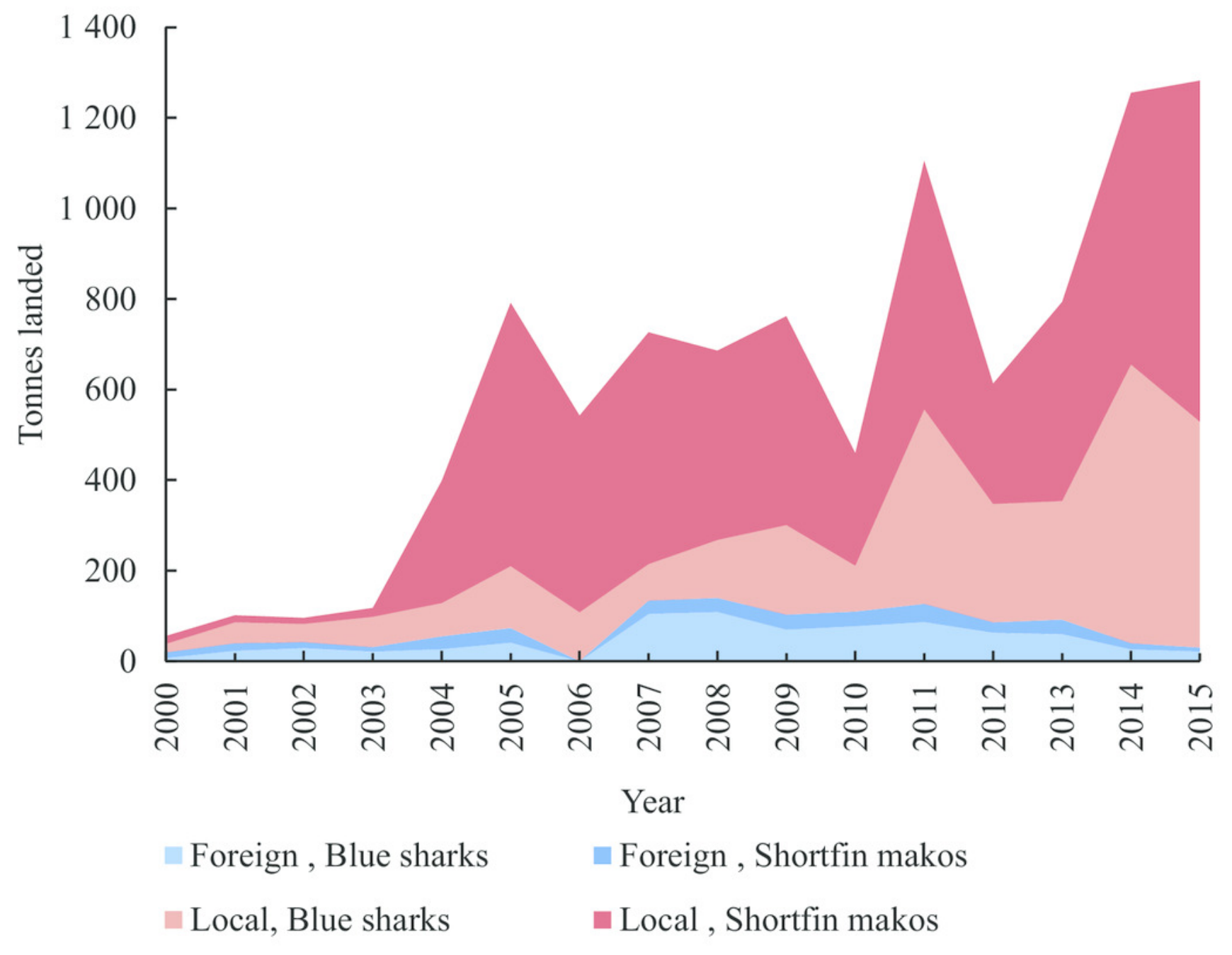


Figure 5

Trends in the numbers of blue and shortfin mako sharks reported by A) local and B) foreign pelagic longline vessels between 2000 and 2015. 
A
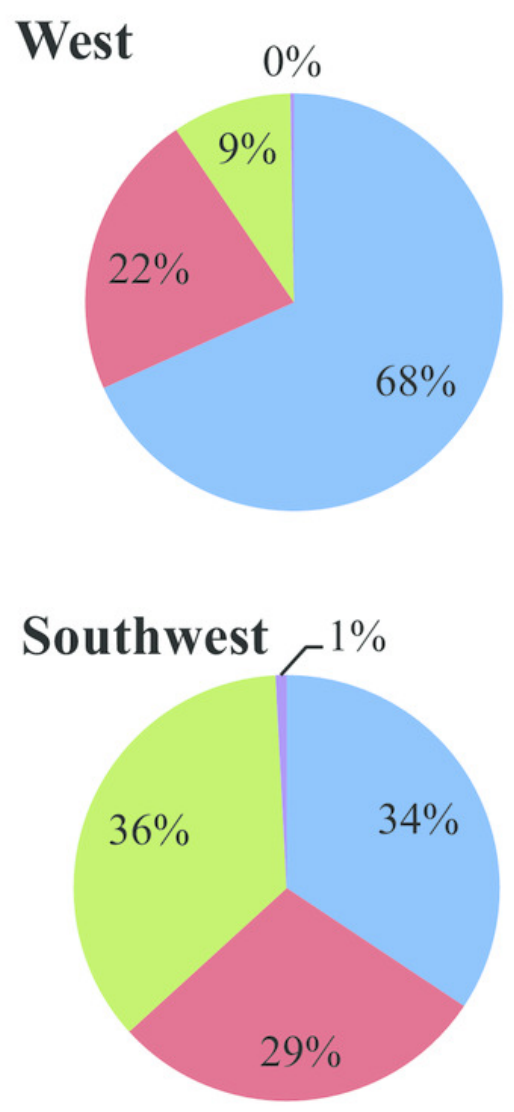

South $\quad 2 \%$
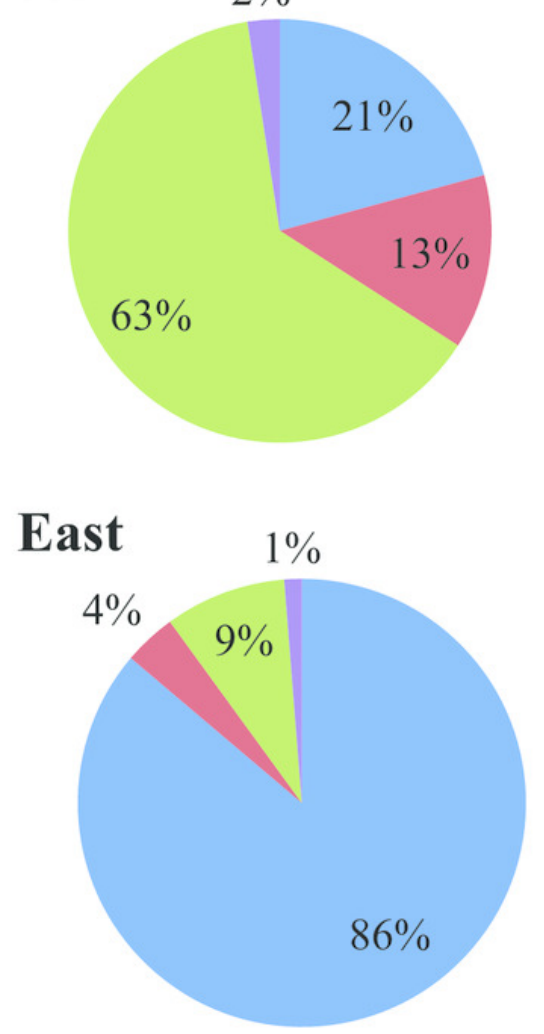

B
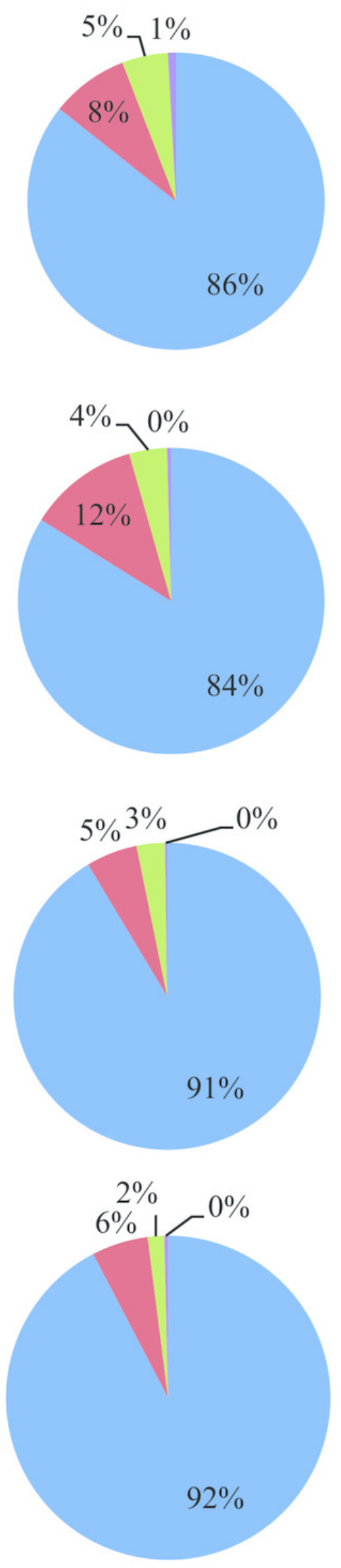

Target species Blue sharks Shortfin makos $\square$ Sharks nei Peer) reviewing PDF | (2017:10:21432:2:0:CHECK 3 Aug 2018) 
Figure 6

Cumulative numbers of A) blue sharks and B) shortfin makos reported in logbooks per area, between 2000 and 2015.

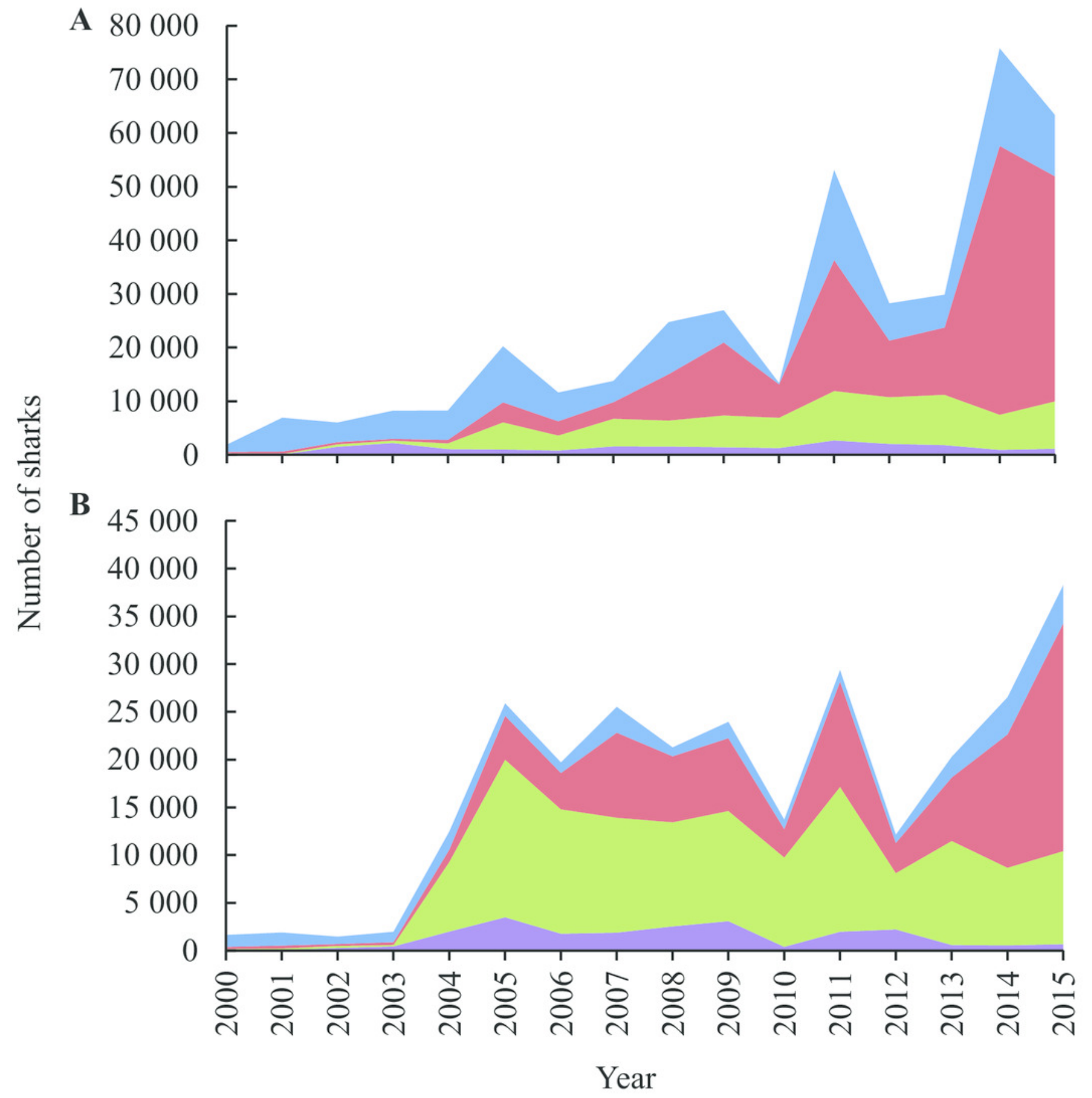

West Southwest South East 
Figure 7

Standardized CPUE indices ( \pm SE) for blue sharks and shortfin makos in the A) West, B) Southwest, C) South and D) East areas, based on the binomial and gamma models applied in the study. 





Figure 8

Average weight $(\mathrm{kg})$ of individual blue sharks caught in each area in 2011, and for all years combined $( \pm S E)$. Total number of sharks $(n)$ is included in the bars.

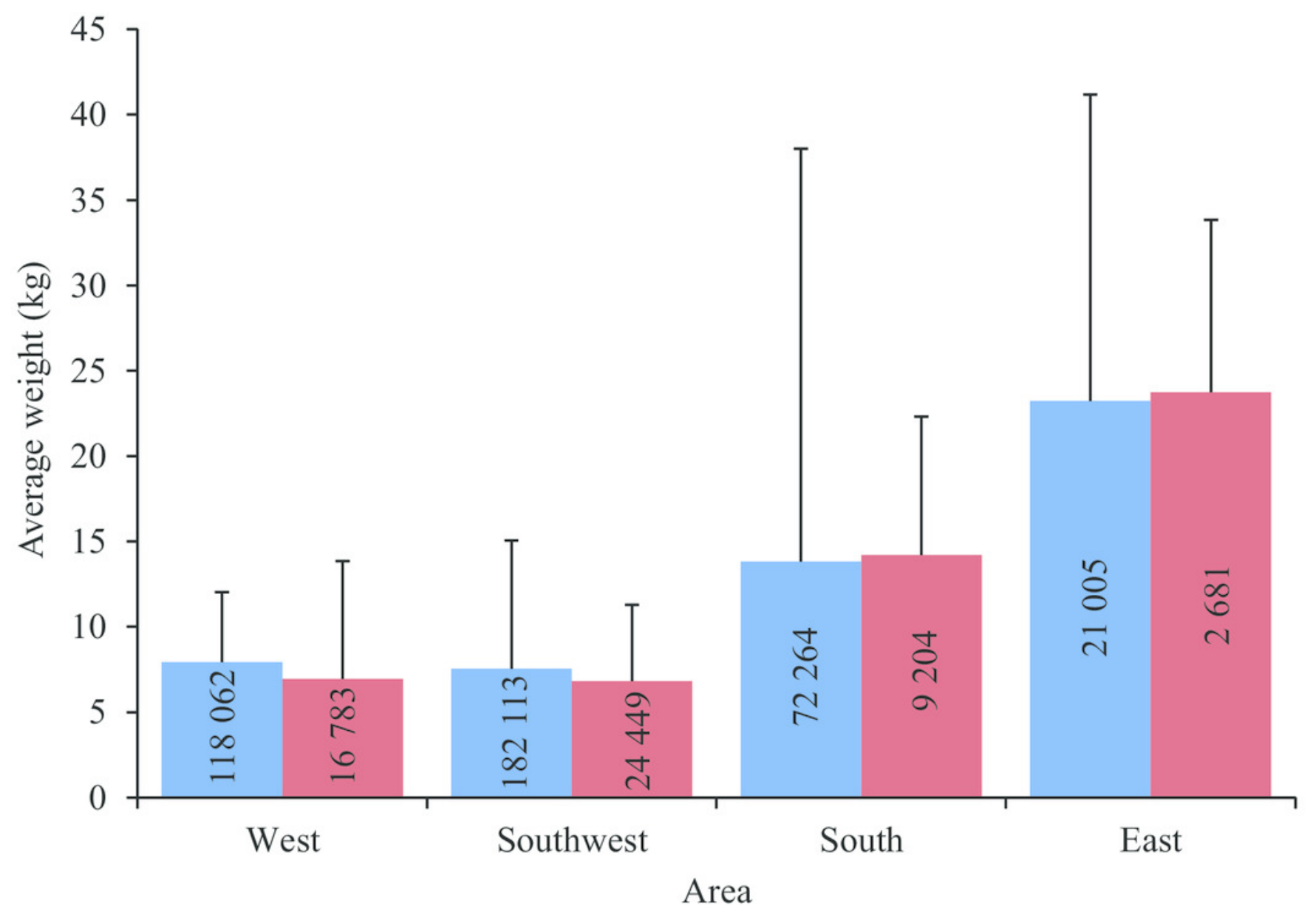

All data $\quad 2011$ 


\section{Table $\mathbf{1}$ (on next page)}

Explanatory variables hypothesised to affect the CPUE of blue sharks and shortfin makos caught by local and foreign pelagic longline fishing vessels from 2000-2015. Models were constructed individually for the West, Southwest, South and East fishing areas 


\begin{tabular}{lll}
\hline Variable & Type and effect & Description \\
\hline Year & Categorical, fixed & 2000-2015 (16 levels) \\
Month & Categorical, fixed & January - December (12 levels) \\
Vessel & Categorical, random & $\begin{array}{l}61 \text { individual local-, and } 49 \text { foreign } \\
\text { vessels }\end{array}$ \\
Fleet & Categorical, fixed & Local, Foreign (2 levels) \\
Observer & Categorical, fixed & Yes, No, Unknown (3 levels)
\end{tabular}

1 


\section{Table 2 (on next page)}

Changes in the regulations pertaining to sharks caught by pelagic longline fisheries in South African waters. 


\begin{tabular}{|c|c|c|}
\hline Year & Changes in regulatory environment & Reference \\
\hline 1998 & - Shark finning prohibited in South Africa & Camhi et al., 2009 \\
\hline 2002 & $\begin{array}{l}\text { - } 100 \% \text { Observer coverage on foreign flagged } \\
\text { vessels in South African waters }\end{array}$ & West and Kerwath, 2015a \\
\hline 2004,2005 & - Shark finning banned by ICCAT and IOTC & Camhi et al., 2009 \\
\hline \multirow[t]{2}{*}{2005} & $\begin{array}{l}\text { Swordfish and tuna longline fishery } \\
\text { commercialised in South Africa }\end{array}$ & Smith, 2005 \\
\hline & $\begin{array}{l}\text { Shark-directed permits abolished, but some } \\
\text { local vessels continue to target sharks under a } \\
\text { permit exemption }\end{array}$ & \\
\hline 2006 & $\begin{array}{l}\text { - } 10 \% \text { Shark bycatch limit and release of live } \\
\text { sharks imposed }\end{array}$ & Clarke and Smith, 2008 \\
\hline \multirow[t]{3}{*}{2011} & $\begin{array}{l}\text { - Shark vessels fishing under exemption fully } \\
\text { amalgamated into tuna and swordfish fisheries }\end{array}$ & da Silva et al., 2015 \\
\hline & $\begin{array}{l}\text { - Sharks managed as bycatch of tuna and } \\
\text { swordfish longline fishery }\end{array}$ & West and Smith, 2012 \\
\hline & $\begin{array}{l}\text { Retention of whitetip (Carcharhinus } \\
\text { longimanus), thresher (Alopias spp.), } \\
\text { hammerhead sharks (Sphyrna spp.) prohibited }\end{array}$ & da Silva et al., 2015 \\
\hline \multirow[t]{3}{*}{2012} & $\begin{array}{l}\text { - Retention of silky sharks (C. falciformis) } \\
\text { prohibited }\end{array}$ & da Silva et al., 2015 \\
\hline & $\begin{array}{l}\text { Precautionary upper catch limit of } 2000 \\
\text { tonnes dressed weight for sharks per year }\end{array}$ & West and Smith, 2013 \\
\hline & - Shark fins to be landed with trunks & West and Smith, 2013 \\
\hline 2014 & $\begin{array}{l}\text { - Tuna and swordfish sub-sectors merged to } \\
\text { become the Large Pelagic Longline Fishery }\end{array}$ & West and Kerwath, 2015b \\
\hline
\end{tabular}

